\section{Nauplius}

The Journal of The

Brazilian Crustacean Society

e-ISSN 2358-2936

www.scielo.br/nau www.crustacea.org.br
This article is part of the special series

offered by the Brazilian Crustacean Society

in honor to Ludwig Buckup in recognition of

his dedication and contributions to the

development of Carcinology

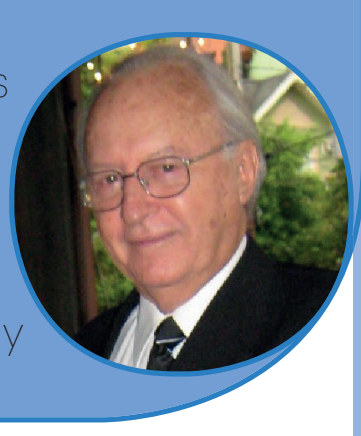

Short Communication

\title{
Color patterns of the hermit crab Calcinus tibicen (Herbst, 1791) fail to indicate high genetic variation within COI gene
}

\author{
Silvia Sayuri Mandai ${ }^{1}$ \\ Raquel Corrêa Buranelli ${ }^{1}$ (D) orcid.org/0000-0002-3092-9588 \\ Fernando Luis Mantelatto ${ }^{1}$ (iD) orcid.org/0000-0002-8497-187X
}
1 Laboratório de Bioecologia e Sistemática de Crustáceos (LBSC), Departamento de Biologia, Faculdade de Filosofia, Ciências e Letras de Ribeirão Preto (FFCLRP), Universidade de São Paulo (USP). Av. Bandeirantes, 3900. 14040-901 Ribeirão Preto, São Paulo, Brazil.
SSM E-mail: silvia.mandai@usp.br RCB E-mail: raquel.buranelli@gmail.com FLM E-mail: flmantel@usp.br

ZOOBANK http://zoobank.org/urn:1sid:zoobank.org:pub:A7CC24B7-E8BB-4925A0C7-3929E7534EDF

\section{Abstract}

Apart from traditional characters, other data have been used for taxonomy, like color patterns. Based on the different colors (green and orange) observed for some Calcinus tibicen (Herbst, 1761) specimens, we evaluated the genetic distance for cytochrome oxidase subunit I mitochondrial gene of individuals collected in Pernambuco (northern Brazil) and in São Paulo (southeast

CORRESPONDING AUTHOR Fernando Luis Mantelatto flmantel@usp.br

SUBMITTED 28 August 2017 ACCEPTED 22 November 2017 PUBLISHED 26 March 2018

Guest Editors

Alessandra A. de Pádua Bueno and Sandro Santos

DOI 10.1590/2358-2936e2018008

\section{(cc) BY}

All content of the journal, except where identified, is licensed under a Creative Commons attribution-type BY.

Nauplius, 26: e2018008 Brazil). We found low genetic variation (0.2-1.1\%), and no evidence of isolation on our molecular tree based on genetic distance. We suggest high levels of gene flow between specimens with different color patterns, which are polymorphisms and might be related to the kind of nutrition as well different ecological and evolutionary predation characteristics.

\section{KEY WORDS}

Anomura, COI gene, coloration, Diogenidae, polymorphism. 
Morphological characters have been used as the main tool of identification and description of decapod crustaceans, but other information such as life history and development, habitat, mating behavior, coloration, and molecular data have become useful for species recognition (Knowlton, 1986; Malay and Paulay, 2009). With the improvement of optical photo equipment and more facilities during field collections during the last two decades, taxonomists have used more frequently color patterns of living animals or the residual patterns found in preserved specimens for species-specific recognition or identification in some decapod groups (e.g. Salmon et al., 1979; Williams and Felder, 1986; Bruce, 1978; Malay and Paulay, 2009; Negri et al., 2014; Hamasaki et al., 2017).

Among hermit crabs, color pattern differentiation is quite significant between cryptic species (e.g. Asakura and Paulay, 2003; Lemaitre and Poupin, 2003; Poupin and Malay, 2009; Negri et al., 2014), and has been considered relevant in the identification of other decapod species (see Poore et al., 2017 for review). In addition, different color patterns may have significance in the reproductive context, such as being decisive in mate choice (e.g., Detto et al., 2006), which may therefore be a barrier of reproductive isolation (Malay and Paulay, 2009). Furthermore, camouflage by coloration is considered a usual anti-predator strategy and might be related to behavioral and morphological mechanisms (e.g. Hamasaki et al., 2017).

The hermit crab genus Calcinus Dana, 1851 includes 43 species (McLaughlin et al., 2010) and is characterized by having morphologically similar species, causing misinterpretations and misidentifications (Haig and McLaughlin, 1983). Even though changes in color are known for some Calcinus species, colors might change markedly and fast during preservation (Haig and McLaughlin, 1983) and this is the main reason why color is frequently rejected in some systematic studies of decapod crustaceans (e.g. Chassard-Bouchaud, 1965; Malay and Paulay, 2009).

In this context, as color patterns have been considered important taxonomic characters for Calcinus species, we sought to evaluate if color differences between some specimens of Calcinus tibicen (Herbst, 1761) co-occurring in the same locality were based on high genetic differences.
We evaluated the genetic distance for the cytochrome oxidase subunit I (COI) mitochondrial gene between six differently colored individuals (orange and green) from the states of Pernambuco (PE, 08 ${ }^{\circ} 16^{\prime} 15.56^{\prime \prime}$ S $\left.34^{\circ} 56^{\prime} 40.34^{\prime \prime} \mathrm{W}\right)$ and São Paulo (SP, 2325'20.03”S 453'42.61”W), Brazil (Fig. 1A, B) [PE orange: CCDB 5327 - GenBank accesses KT897571, KT897572; PE green: CCDB 5328 - GenBank accesses KT897552, KT897570; SP orange: CCDB 0769 - GenBank access KT897493; SP green: CCDB 0778 - GenBank access KT897522]. The identification of the specimens was confirmed based on morphological characters (Melo, 1999). Here we report that the green pattern has changed its color after preservation in $70 \%$ ethanol.

General molecular analysis protocols followed Schubart et al. (2000), with modifications according to Mantelatto et al. (2006). For DNA extraction, salting-out extraction method (Miller et al., 1988) was used, with changes aiming suitability to the material. The primers $\mathrm{COH} 6$ (5'TADACTTCDGGRTGDCCAAARAAYCA-3) and COL6b (5'-ACAAATCATAAAGATATYGG-3') (Schubart and Huber, 2006) were used in amplification by means of a Polymerase Chain Reaction (PCR) (Sambrook et al., 1989). Thermocycling conditions included: initial denaturation $\left(2 \mathrm{~min}\right.$ at $\left.94^{\circ} \mathrm{C}\right), 35$ annealing cycles $\left(94^{\circ} \mathrm{C}\right.$ for $30 \mathrm{~s} ; 50^{\circ} \mathrm{C}$ for $30 \mathrm{~s} ; 72^{\circ} \mathrm{C}$ for $1 \mathrm{~min})$; final extension $\left(2 \mathrm{~min}\right.$ at $\left.72^{\circ} \mathrm{C}\right)$. PCR products were purified using the kit SureClean and sequenced with the ABI Big Dye Terminator Mix (Applied Biosystem, Carlsba, CA, USA) in an ABI 3730xl DNA Analyzer (Applied Biosystems automated sequencer). Sequences were edited, and a consensus sequence was obtained from both strands (forward and reverse directions), using the program BioEdit 7.2.5.0 (Hall, 1999). Sequences (608 base pairs) were aligned via Clustal W (Thompson et al., 1994) with interface to BioEdit 7.2.5.0 (Hall, 1999). Matrixes of genetic divergence were computed in the program Molecular Evolutionary Genetics Analysis (MEGA) 6, using Kimura 2-parameters (Kimura, 1980). A Neighbor Joining tree was constructed using the software MEGA 6 (Tamura et al., 2013) based on genetic distance. In this analysis we used the following species as outgroups: Calcinus californiensis Bouvier, 1898 (GenBank access: KT89759), Calcinus explorator Boone, 1930 (GenBank 

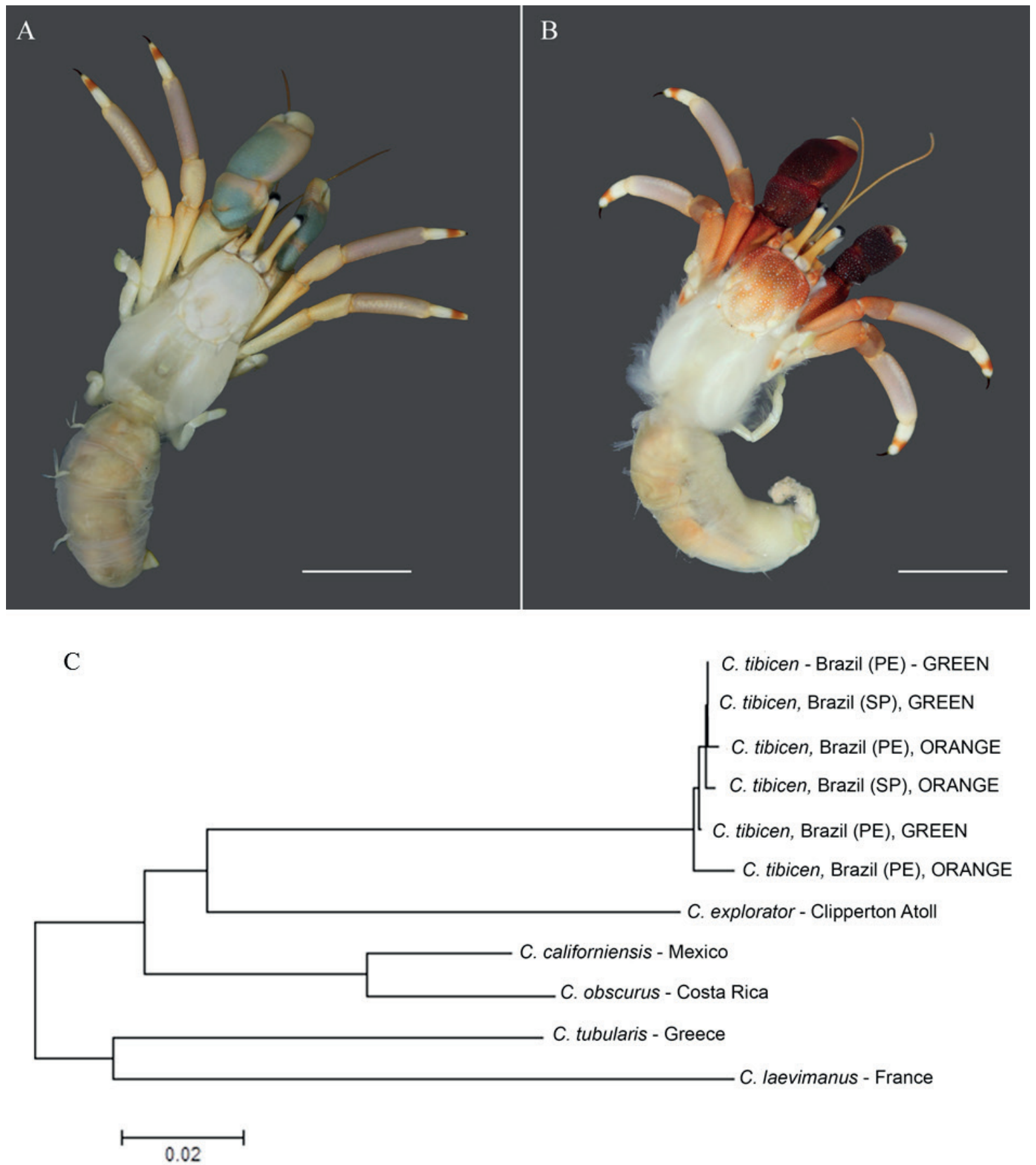

Figure 1. Specimens of Calcinus tibicen (Herbst, 1761) from two Brazilian localities (PE: Pernambuco and SP: São Paulo), showing differences in the color patterns of the chelae in life. (A) green claw male, CCDB 5328, scale bar = 10 mm. (B): orange claw male, CCDB 5327, scale bar $=11 \mathrm{~mm}$ (both from Pernambuco). (C) Neighbor Joining tree of $C$. tibicen specimens based on genetic distance for COI gene. Photos by R.C. Buranelli.

access: FJ620320), Calcinus laevimanus (Randall, 1840) (GenBank access: FJ620270), Calcinus obscurus Stimpson, 1859 (GenBank access: KT897589) and Calcinus tubularis (Linnaeus, 1767) (GenBank access: KT897590).

Our results showed high levels of genetic homogeneity $(0.2-1.1 \%$ of variation), and the
Neighbor Joining tree based on the genetic distance also pointed out no isolation amongst the differently colored specimens - geographically separated by more than $2.500 \mathrm{~km}$ - of C. tibicen from Pernambuco and São Paulo (Fig. 1C); the opposite, i.e. high levels of variation (15.5-23.3\%), was observed when comparing these colored individuals with the outgroups. These 
data indicate that these patterns are polymorphisms of the species as reported for other decapods (e.g. Terossi and Mantelatto, 2010), and are probably related to ecological factors, but hardly to a reproductive barrier.

Here we suggest some ecological factors, nonexclusive, probably related to the color patterns of the chelae: thermoregulation, intraspecific communication, and camouflage (Endler, 1978). The tons of the animals, in general, tend to be similar to their backgrounds (e.g. Poulton, 1890; Duarte et al., 2016), and in this case, some of the animals were collected in association and/or close to the red or green algae banks (FLM, pers. obs.). It means that individuals with orange or green chelae inhabit the same region, nevertheless, they can occupy different habitats with distinct background coloration, what might represent camouflage aspects, as already reported for other decapods (e.g. Bauer, 1981; Duarte et al., 2016). Morphology, coloration, and behavior can be linked to different ecological and evolutionary predation pressure under the same habitat (Hacker and Madin, 1991), related to predator color vision and predator color acuity (Endler, 1978). Natural predators of C. tibicen in this situation might be the fish Diodon hystrix Linnaeus, 1758 (Randall, 1967), and invertebrates such as Octopus vulgaris Cuvier, 1797 and Octopus briareus Robson, 1929 (Gilchrist, 2003). Then, the variation in the chelae continued in C. tibicen's populations representing adaptive significance against different predators and the color patterns can be an interesting way of camouflage against visually-hunting predators (Bauer, 1981; Hamasaki et al., 2017). Due to the relationship with the substrate, it can also be conjectured that the tons of colors are also related to the kind of nutrition of the specimens.

Therefore, although in genus Calcinus color patterns are taken to species-specific recognition or identification, in the case of $C$. tibicen evaluated here, this characteristic may not be used (in opposition to what was reported in Salmon et al., 1979; Bruce, 1978; Malay and Paulay, 2009; Negri et al., 2014; Hamasaki et al., 2017). Both colors of chelae occur within the same species, which was represented by the low rates of genetic variation among them and when compared with the genetic range of variation (0-9.9\%) observed along the entire $C$. tibicen distribution in the Western Atlantic (Mandai et al., unpublished data). Some causes related to these differences in colors of the chelae, orange or green, were inferred here; however, more studies about C. tibicen's ecology and feeding might be taken to better understand this intriguing pattern in some regions of its distribution.

\section{ACKNOWLEDGEMENTS}

This article was part of the Bachelor's thesis of SSM supported by scientific fellowship of Fundação de Amparo à Pesquisa do Estado de São Paulo - FAPESP (2014/10639-1). Major financial support was provided by FAPESP (2002/081789, Temático Biota 2010/50188-8; Coleções Científicas 2009/54931-0; APQ 2016/50376-5), Conselho Nacional de Desenvolvimento Científico e Técnológico - CNPq (Procs. 473050/2007-2, 471011/2011-8, 504322/2012-5; Research Scholarship PQ302748/2010-5, 304968/2014-5) and Coordenação de Aperfeiçoamento de Pessoal de Nível Superior - CAPES (Ciências do Mar II 2005/2014 - 23038.004308/2014-14) to FLM. RCB thanks the Post-Doctoral fellowship by CNPQ (PROTAX $150462 / 2016-6)$. We thank anonymous reviewers for their suggestions that help to improve the quality of this paper during revision process. The authors, especially FLM, are honored to recognize the many achievements of our colleague, Ludwig Buckup, to development of carcinology in Brazil and for this reason dedicate this contribution for this commemorative edition to him.

\section{References}

Asakura, A. and Paulay, G. 2003. Pylopaguropsis lemaitrei, a new species of hermit crab (Decapoda: Anomura: Paguridae) from French Polynesia. Crustacean Research, 32: 13-25.

Bauer, R.T. 1981. Color Patterns of the Shrimps Heptacarpus pictus and $H$. paludicola (Caridea: Hippolytidae). Marine Biology, 64: 141-152.

Bruce, A.J. 1978. The evolution and zoogeography of shallowwater tropical shrimps. Information Series, Department of Scientific and Industrial Research, New Zealand, 137: 337-355.

Chassard-Bouchaud, C. 1965. L'adaptation chromatique chez les Natantia (Crustacés Décapodes). Paris, Robin \& Mareuge, $104 p$.

Detto, T.; Backwell, P.R.; Hemmi, J.M. and Zeil, J. 2006. Visually mediated species and neighbor recognition in fiddler crabs (Uca mjoebergi and Uca capricornis). Proceedings of the Royal Society B: Biological Sciences, 273: 1661-1666.

Duarte, R.C.; Stevens, M. and Flores, A.A.V. 2016. Shape, colour plasticity, and habitat use indicate morph-specific camouflage strategies in a marine shrimp. BMC Evolutionary Biology, 16: 218-232. 
Endler, J.A. 1978. A Predator's View of Animal Color Patterns. p. 319-364. In: M.K. Hecht; W.C. Steere and B. Wallace (eds), Evolutionary Biology, Vol. 11. Boston, Springer.

Gilchrist, S.L. 2003. Hermit crab population ecology on a shallow coral reef(Bailey's Cay, Roatan, Honduras): octopus predation and hermit crab shell use. Memoirs of Museum Victoria, 60: $35-44$.

Hacker, S.D. and Madin, L.P. 1991. Why habitat architecture and color are important to shrimps living in pelagic Sargassum: use of camouflage and plant-part mimicry. Marine Ecology Progress Series, 70: 143-155.

Haig, J. and Mclaughlin, P.A. 1983. New Calcinus species (Decapoda: Anomura: Diogenidae) from Hawaii, with a key to the local species. Micronesica, 19: 107-121.

Hall, T.A. 1999. BioEdit: a user-friendly biological sequence alignment editor and analysis program for Windows 95/98/ NT. Nucleic Acids Symposium Series, 41: 95-98.

Hamasaki, K.; Tsuru, T.; Sanda, T.; Fujikawa, S.; Dan, S. and Kitada, S. 2017. Ontogenetic change of body color patterns in laboratory-raised juveniles of six terrestrial hermit crab species. Zootaxa, 4226: 521-545.

Kimura, N. 1980. A simple method for estimating evolutionary rates of base substitutions through comparative studies of nucleotide sequences. Journal of Molecular Evolution, 16: 111-120.

Knowlton, N. 1986. Cryptic and sibling species among the Decapod Crustacea. Journal of Crustacean Biology, 6: 356-363.

Lemaitre, R. and Poupin, J. 2003. A strikingly coloured new species of Paragiopagurus Lemaitre, 1996 (Crustacea: Decapoda: Anomura: Parapaguridae) from French Polynesia. Zootaxa, 386: 1-11.

Malay, M.C.M.D. and Paulay, G. 2009. Peripatric speciation drives diversification and distributional pattern of reef hermit crabs (Decapoda: Diogenidae: Calcinus). The Society for the Study of Evolution, 64: 634-662.

Mantelatto, F.L.; Robles, R.; Biagi, R. and Felder, D.L. 2006. Molecular analysis of the taxonomic and distributional status based for the hermit crab genera Loxopagurus Forest, 1964, and Isocheles Stimpson, 1858 (Decapoda, Anomura, Diogenidae). Zoosystema, 28: 495-506.

McLaughlin, P.A.; Komai, T.; Lemaitre, R. and Rahayu, D.L. 2010. Annotated checklist of Anomuran Decapod crustaceans of the world (exclusive of the Kiwaoidea and families Chirostylidae and Galatheidae of the Galatheoidea). Part I - Lithodoidea, Lomisoidea and Paguroidea. The Raffles Bulletin of Zoology, Supplement 23: 5-107.

Melo, G.A.S. 1999. Manual de identificação dos Crustacea Decapoda do litoral brasileiro: Anomura, Thalassinidea, Palinuridea, Astacidea. São Paulo, Plêidae, 551p.

Miller, S.A.; Dykes, D.D. and Polesky, H.F. 1988. A simple salting out procedure for extracting DNA from human nucleated cells. Nucleic Acids Research, 16: 1215.
Negri, M.; Lemaitre, R. and Mantelatto, F.L. 2014. Molecular and morphological resurrection of Clibanarius symmetricus (Randall, 1840), a cryptic species hiding under the name for the "thinstripe" hermit crab C. vittatus (Bosc, 1802) (Decapoda: Anomura: Diogenidae). Journal of Crustacean Biology, 34: 848-861.

Poore, A.G.B.; Ahyong, S.T.; Lowry, J.K. and Sotk, E.E. 2017. Plant feeding promotes diversification in the Crustacea. PNAS, 114: 8829-8834.

Poulton, E.B. 1890. The colors of animals, their meaning and use, especially considered in the case of insects. New York, D. Appleton and Company, 365p.

Poupin, J. and Malay, M.C.M.D. 2009. Identification of a Ciliopagurus strigatus (Herbst, 1804) species-complex, with description of a new Ciliopagurus from French Polynesia (Decapoda, Anomura, Diogenidae). Zoosystema, 31: 209-232.

Randall, J.E. 1967. Food habits of reef fishes of the West Indies. Studies in Tropical Oceanography, 5: 665-847.

Salmon, S.D.; Ferris, D.; Johnston, G.; Hyatt, G. and Whitt, G.S. 1979. Behavioral and biochemical evidence for species distinctiveness in the fiddler crabs, Uca speciosa and $U$. spinicarpa. Evolution, 33: 182-191.

Sambrook, J.; Fritsch, E.F. and Maniatis, T. 1989. In vitro amplification of DNA by the Polymerase Chain Reaction, p. 2-35. In: J. Sambrook; E.F. Fritsch and T. Maniatis (eds), Molecular cloning: a laboratory manual. New York, Cold Spring Harbor Laboratory Press.

Schubart, C.D. and Huber, M.G.J. 2006. Genetic comparisons of german populations of the stone crayfish, Austropotamobius torrentium (Crustacea: Astacidae). Bulletin Francais de la Peche et de la Pisciculture, 380: 1019-1028.

Schubart, C.D.; Neigel, J.E. and Felder, D.L. 2000. Use of the mitochondrial 16S rRNA gene for phylogenetic and population studies of Crustacea. In: J.C. von Vaupel Klein and F.R. Schram (eds), The Biodiversity Crisis and Crustacea - Proceedings of the 4th International Crustacean Congress, Balkema, Rotterdam, Brookfield, The Netherlands. Crustacean Issues, 12: 817-830.

Tamura, K.; Stecher, G.; Peterson, D.; Filipski, A. and Kumar, S. 2013. MEGA6: Molecular Evolutionary Genetics Analysis Version 6.0. Molecular Biology and Evolution, 30: 2725-2729.

Terossi, M. and Mantelatto, F.L. 2010. Sexual ratio, reproductive period and seasonal variation of the gonochoric shrimp Hippolyte obliquimanus (Caridea: Hippolytidae). Marine Biology Research, 6: 213-219.

Thompson, J.D.; Higging, D.G. and Gibson, T.J. 1994. CLUSTALW: Improving the sensitivity of progressive multiple sequence alignment through sequence weighting specific gap penalties and weight matrix choice. Nucleic Acids Research, 22: 4673-4680.

Williams, A.B. and Felder, D.L. 1986. Analysis of stone crabs: Menippe mercenaria (Say), restricted, and a previously unrecognized species described (Decapoda: Xanthidae). Proceedings of the Biological Society of Washington, 99: 517-543. 